\title{
Sintered Materials Based on Copper and Alumina Powders Synthesized by a Novel Method
}

\author{
Marija Korać1, Željko Kamberović2 ${ }^{\text {, Zoran Anđić }{ }^{3} \text { and Mirjana Filipović }}{ }^{2}$ \\ Innovation center of the Faculty of Technology and Metallurgy in Belgrade, \\ ${ }^{2}$ Faculty of Technology and Metallurgy, University of Belgrade, \\ ${ }^{2}$ Scientific Research Center, Užice, \\ Serbia
}

\section{Introduction}

The intensification in research of nanostructure materials that occurred in recent years was mainly due to their striking potential, i.e. mechanical and physical properties significantly improved compared to the conventional grain materials (Moriarty, 2001; Ristić, 2003).

Nano-structured materials rank in the group of ultra fine, metastable structures containing a high concentration of defects (point defects, dislocations) and boundaries (grain boundaries, interphase boundaries, etc.). These materials are structurally different from crystals and amorphous forms because of the fact that grain boundaries and interphases represent a specific state of the solid matter, since the atoms on boundaries are subjected to a periodical potential field of the crystal from both sides of the boundary (Koch, 1999).

The synthesis of powders represents the starting and crucial stage in the production of sintered metal materials with required properties. Considering that the starting structure undergoes certain changes during further processing, but remains essentially preserved in the structure of the final product (Ristić, 2003; Motta et al. 2004), there is an increased necessity for a great number of methods for producing powders.

Copper is widely exploited in industry because of its high electrical and thermal conductivity, even though it possesses low strength especially at elevated temperatures. In order to overcome this problem it can be strengthened by using finely dispersed particles of stable oxides like alumina, titania, yttria etc. Copper-based composite materials are widely applied in the field of electronics and electrical engineering as highly conductive materials for operation at elevated temperatures, as electrodes for resistance spot and seam welding, different contact materials, various switches, thermal and electric conductors, microwave tubes, etc (Lee \& Kim, 2004).

Introduction of fine dispersed particles into matrix of base-metal has considerable strengthening effect and nano particles of oxides are especially suitable. Due to their hardness, stability at elevated temperatures and insolubility in copper they represent obstacles for dislocation, grain and sub-grain boundary movement increasing mechanical properties of these materials with insignificant effect on thermal and electrical conductivity (Naser et al., 1997; Trojanova et al., 1999, Tian et al. 2006). Significant reinforcing effects can 
be kept even at elevated temperatures. For such reinforcement nano-particles of oxides are suitable (Karwan-Baczewska, 2005).

A very important aspect of dispersion strenghtening is introduction of low volume fraction of dispersed oxide particles into the volume of the base-metal, a uniform distribution of oxide particles and their fine dispersion especially in nanometer scale (Ristic \& Milosevic, 2006).

Alumina was known for its exceptional properties such as high melting point, high hardness, excellent thermal stability and chemical inertness. Also, addition of alumina particles can increase the temperature of recrystallization by pinning grain and sub-grain boundaries of copper matrix and blocking the movement of dislocations highly improving strength at elevated temperatures (Plascencia \& Utigard, 2005; Lianga et al., 2004). The usual amount of alumina used for dispersion strengthening is from 0.5-5.0 wt.\% (Jena et al., 2004), but significant results regarding particle size could be achieved with even higher amounts ranging up to $50 \mathrm{wt}$ \% alumina (Brocchi et al., 2004).

Because these oxides are not soluble in copper $\mathrm{P} / \mathrm{M}$ techniques must be used instead of conventional ingot metallurgy. Oxide dispersion strengthened (ODS) copper can be successfully synthesized by following methods: highly energetic reactive milling (Ahn et al., 1996), precipitation from solution (sol-gel (Ruys \& Mai, 1999), hydrothermal synthesis (Byrappaa \& Adschirib, 2007), electrochemical synthesis (Yuana et al., 2007)), internal oxidation (Afshar \& Simichi, 2008) etc. The production of powders by the thermo-chemical method is not a new procedure, but in recent years, due to the development of contemporary materials with pre-set properties, there has been an extended interest in this method, especially for the production of nanostructured powders (Wu et al., 2001; Jena et al. 2001; Lee et al, 2001).

Route for synthesis of composite powders based on copper and alumina presented in this research, may be regarded as new for materials in this system, even though phases of this process have been previously investigated by the authors (Korać et al., 2005; Anđić et al., 2006; Anđić et al., 2007a; Anđić, 2007b; Korać et al., 2008a, Korać et al., 2008b) and also previous attempts have been made for application of similar process in system $\mathrm{Cu}$-Ag$\mathrm{Al}_{2} \mathrm{O}_{3}$, when a three-component system was produced by mechanically alloying the thermochemically synthesized $\mathrm{Cu}-\mathrm{Al}_{2} \mathrm{O}_{3}$ and $\mathrm{Cu}$-Ag powder (Anđić et al., 2006).

Objective of this research was to investigate the possibility of copper strengthening with fine dispersed alumina particles by application of new synthesis method and production of sintered materials with properties suitable for material application as contact material.

After sintering compacts were thermo-mechanically treated in order to simulate real manufacturing process.

Verification of obtained results is performed by tribological investigations.

\section{Experimental}

Generally synthesis process included two separate routes. The first included synthesis of $\mathrm{Cu}-\mathrm{Al}_{2} \mathrm{O}_{3}$ with 50 wt. \% of $\mathrm{Al}_{2} \mathrm{O}_{3}$ (from now on $\mathrm{Cu}-50 \mathrm{Al}_{2} \mathrm{O}_{3}$ ) by thermo-chemical route. The second part of the synthesis process was mechanical alloying of atomized copper powder with powder of $\mathrm{Cu}-\mathrm{Al}_{2} \mathrm{O}_{3}$ previously synthesized.

Starting raw materials for powder synthesis by thermo-chemical route were soluble salts, nitrates of copper and aluminum of p.a. quality, dissolved in distilled water (50wt.\% solution) in suitable ratio for final powder to contain $50 \mathrm{wt} . \%$ of $\mathrm{Al}_{2} \mathrm{O}_{3}$ in structure.

Copper powder used in mechanical alloying stage was produced by atomization with particle size $95 \%<45 \mu \mathrm{m}$. In previous research (Korać, 2005) electrolytic copper was used for 
mechanical alloying. Electrolytic copper was replaced with atomized, due to the fact that its dendrite structure prevents formation of homogenous structure of final material, even after prolonged milling time.

Stages of synthesis process included the following processes:

1. Spray drying of nitrate solution using Spray Dryer Büchi B-290 Advanced (Okuyama \& Lenggoro, 2003) with inlet/outlet temperature $190 / 143^{\circ} \mathrm{C}$ and solution flow rate was $10 \%$ of pump power,

2. Dried nitrates were subjected to heat treatment in a laboratory electroresistant tube furnace (Korać et al., 2009) in air at $900^{\circ} \mathrm{C}$ for $1 \mathrm{~h}$ in order to form oxides of copper and aluminium,

3. Oxides were then reduced in the same furnace in hydrogen atmosphere (flow rate $20 \mathrm{~L} / \mathrm{h}$ at $350^{\circ} \mathrm{C}$ for $1 \mathrm{~h}$ ) in order to obtain metallic copper. Previously formed stable $\mathrm{Al}_{2} \mathrm{O}_{3}$ remained unchanged during reduction (Korać et al., 2009),

4. Mechanical alloying was the next step in the synthesis process. Atomized copper powder was mechanically alloyed with produced composite powder with 50wt.\% $\mathrm{Al}_{2} \mathrm{O}_{3}$ in a ceramic ball mill, with dimensions $ø 180 \times 160 \mathrm{~mm}$. Milling media were corundum balls ( $\geq 99 \% \mathrm{Al}_{2} \mathrm{O}_{3}$ with $30 \mathrm{~mm}$ in diameter) in order to prevent contamination of material; ball to powder ratio was 1:30. Optimal milling time was fixed at $5 \mathrm{~h}$ for mill rotation of $300 \mathrm{~min}^{-1}$. Quantities of added copper powder were adjusted so that the final amount of alumina $\mathrm{Al}_{2} \mathrm{O}_{3}$ in composite powder would contain $1,1.5$ and $2 \mathrm{wt}$. \%.

Flow-sheet of applied synthesis process is presented in Fig. 1.

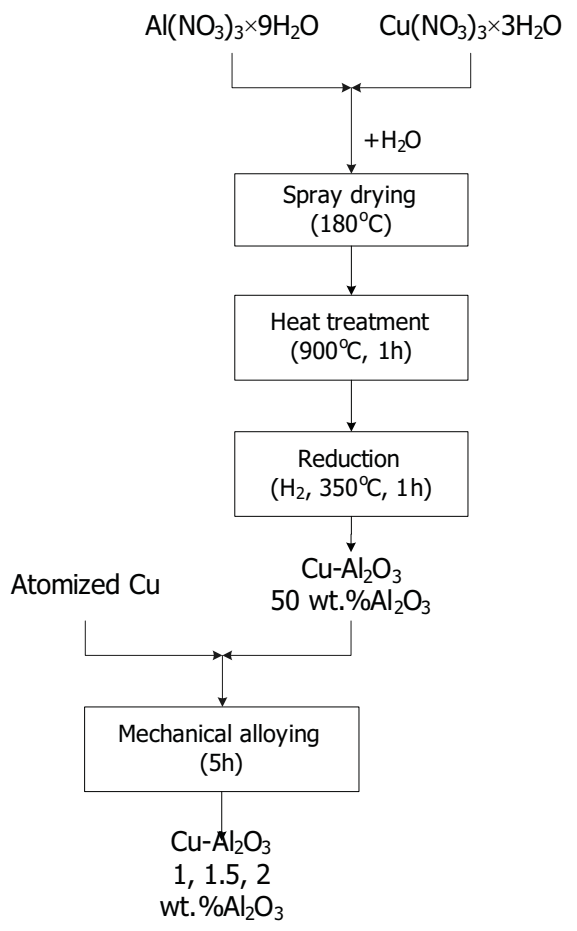

Fig. 1. Flow-sheet for the synthesis of $\mathrm{Cu}-\mathrm{Al}_{2} \mathrm{O}_{3}$ composites 
Solution concentration of $50 \%$ enabled production of higher amounts of fine particles. If solution concentration was increased coarse particles would be produced, which could disable fine coating of copper particles in later stage of mechanical alloying. On the other hand if solution was too diluted, finer particles would be obtained, but disadvantage is that in this case synthesis process would last longer, with higher equipment engagement, i.e. lower possibilities for industrial application.

Method of choice for acquiring of precursor powder was spray drying. In recent years this method is engaged in large share for production of micron and sub-micron powders (McCandlish et al., 1994). Advantages of this drying method are control of size, morphology and particle composition, as well as significant possibility of industrial application from aspect of price-productivity ratio (Okuyama \& Lenggoro, 2003; Iskandar et al., 2003). Also, application of this drying method in $\mathrm{Cu}-\mathrm{Al}_{2} \mathrm{O}_{3}$ system showed very good results in previous research (Anđić, 2006; Korać; 2007).

Temperatures of heat treatment and reduction were previously optimized for this system (Anđić, 2006), as well as milling condition (Korać, 2005).

After mechanical alloying obtained powders were compacted by a uniaxial pressing in order to minimize density gradient trough sample. Used tool had dimensions $8 \times 32 \mathrm{~mm}$ and height $3 \mathrm{~mm}$, and applied compacting pressure was $500 \mathrm{kN}$.

Sintering of samples was performed in hydrogen atmosphere in isothermal conditions at five different temperatures in the range from $725-925^{\circ} \mathrm{C}$ for 15 to $120 \mathrm{~min}$.

After consolidation of the obtained powders, the compacted samples were uniaxially compressed by cold rolling, reduction degree of 15 and $30 \%$. In order to determine the stability at higher temperatures, the rolled samples were annealed at temperature of $800^{\circ} \mathrm{C}$ for one hour in the hydrogen atmosphere.

Produced powders were characterized by X-ray diffraction analysis (XRD). XRD was performed using APD 2000-Ital structures with $\mathrm{CuK} \alpha$ radiation, $2 \theta=0-100^{\circ}$.

Characterization of sintered samples (referred as composite in the following text) included Scanning Electron Microscopy (SEM), Energy Dispersive Spectrometry (EDS), HRF hardness measurements and electrical conductivity.

SEM analysis was performed on JEOL JSM-T20 on polished samples subsequently etched with 40 vol.\% $\mathrm{HNO}_{3}$ solution. EDS analysis was conducted on unpolished composites using Oxford system attached to JEOL SEM JSM-5800.

Ames Portable Hardness Tester was employed for hardness measurements using 1/16" ball with applied load of $60 \mathrm{~kg}$. For electrical conductivity measurement Foerster Sigma Test 2.069 operating at $120 \mathrm{kHz}$ and with $8 \mathrm{~mm}$ electrode diameter, was used.

Values of hardness and electrical conductivity represent the mean value of at least six measurements conducted on the same composite.

Wear testing was performed by the method of Taber in accordance with Guide to friction, wear and erosion testing (ASTM standard MNL 56, 2007). Basic information on test conditions are:

- diameter of the grinding plate $-640 \mathrm{~mm}$,

- diameter of the grinding path - 265mm,

- calculated speed rate of the grinding path $-832.5 \mathrm{~mm}$

- granulation of Corundum $\mathrm{Al}_{2} \mathrm{O}_{3} \varnothing 100 \mu \mathrm{m}$.

\section{Results \& discussion}

It was expected that by the proposed synthesis method nano-composite $\mathrm{Cu}-\mathrm{Al}_{2} \mathrm{O}_{3}$ produced by thermo-chemical route would form homogenous compact layer around atomized copper 
powder particles during mechanical alloying process. This way a ductile, highly conductive core with high strength shell layer of composite, will be achieved. In later stages this microstructure would provide dislocation blocking and prevent grain boundary motion as well as an increase of recrystallization temperature.

\subsection{Powder characterization}

SEM analysis of $\mathrm{Cu}-50 \mathrm{Al}_{2} \mathrm{O}_{3}$ presented in Figure 2 shows that powders are flake like with average particle size of $200-400 \mathrm{~nm}$, which have partially agglomerated due to their small size and high surface energy. Average size of present agglomerates is $1-5 \mu \mathrm{m}$.

Previous results on thermo-chemical synthesis of $\mathrm{Cu}-\mathrm{Al}_{2} \mathrm{O}_{3}$ powders (Korać, 2005) indicates that presented particles in fact represent very fine agglomerates, and that actual size of synthesized powder is in range $20-50 \mathrm{~nm}$.

X-ray diffraction pattern of powder containing $50 \mathrm{wt} . \% \mathrm{Al}_{2} \mathrm{O}_{3}$ is presented in Figure 3. Identified peaks correspond to $\mathrm{Cu}$ and $\mathrm{CuAl}_{2} \mathrm{O}_{4}$. $\mathrm{CuAl}_{2} \mathrm{O}_{4}$ phase represents the metastable equilibria, developed in microstructure during powder synthesis process, heat treatment and reduction.

Thermo-chemically synthesized powder was used for mechanical alloying of electrolytic copper, SEM micrograph presented in Figure 4.

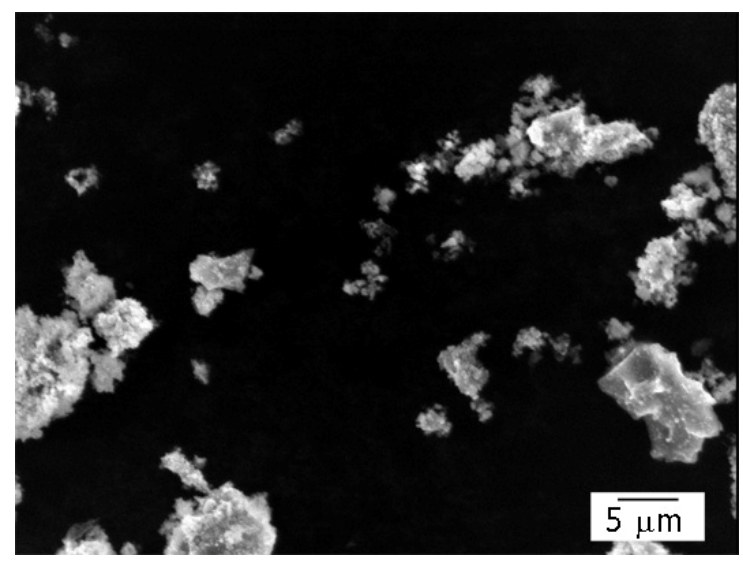

Fig. 2. SEM micrograph of $\mathrm{Cu}-50 \mathrm{Al}_{2} \mathrm{O}_{3}$ powder

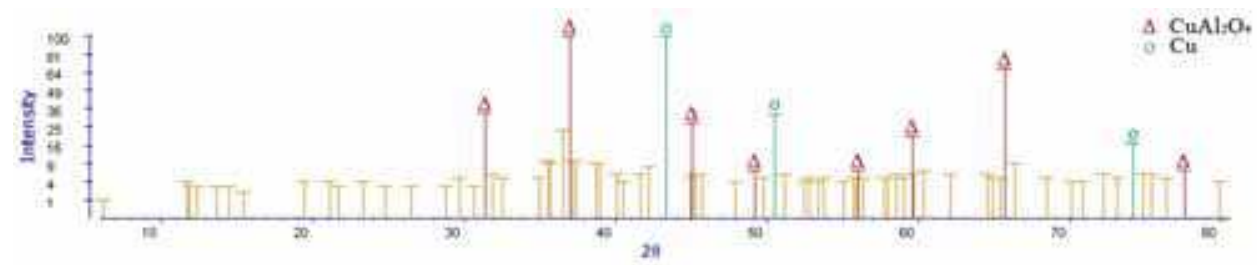

Fig. 3. X-ray diffraction of $\mathrm{Cu}-50 \mathrm{Al}_{2} \mathrm{O}_{3}$ powder

Used copper powder particles are mostly spherical shaped with smooth surface. This particle morphology enables achievement of desired structure with highly conductive core with homogenous shell layer around it. 


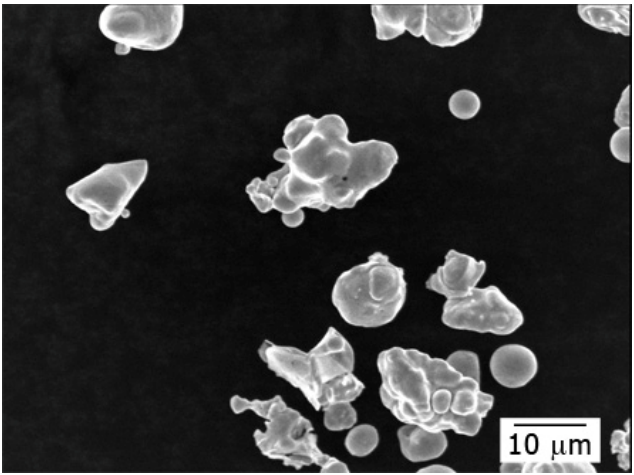

a)

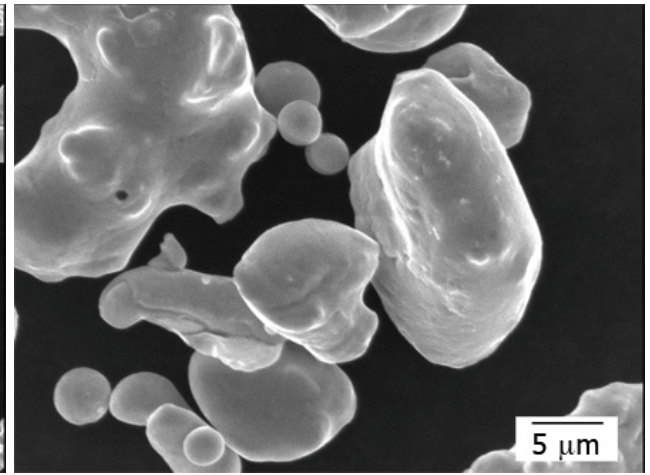

b)

Fig. 4. SEM micrographs of electrolytic copper powder

After $5 \mathrm{~h}$ of milling of powders, all three compositions showed structure characteristic for mechanical alloying (Figures 5-7).

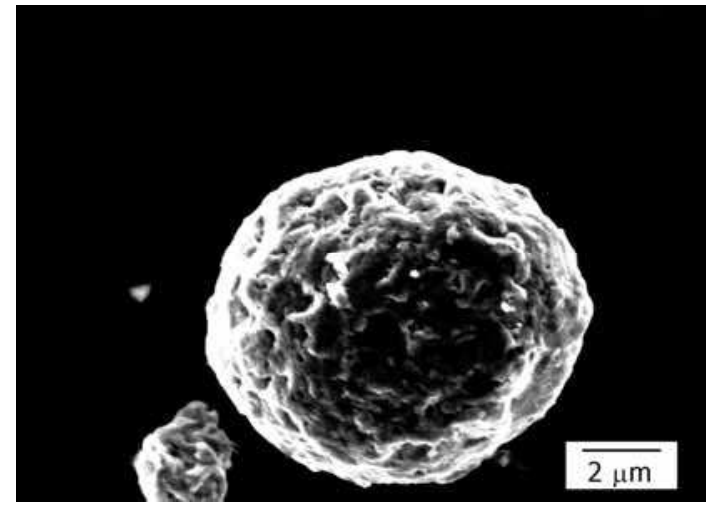

Fig. 5. SEM micrograph of composite powder containing 1 wt. $\%$ of $\mathrm{Al}_{2} \mathrm{O}_{3}$

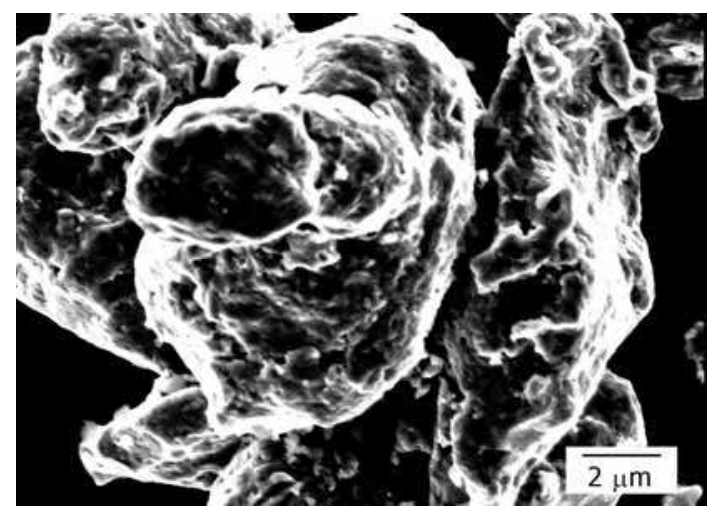

Fig. 6. SEM micrograph of composite powder containing $1.5 \mathrm{wt} . \%$ of $\mathrm{Al}_{2} \mathrm{O}_{3}$ 


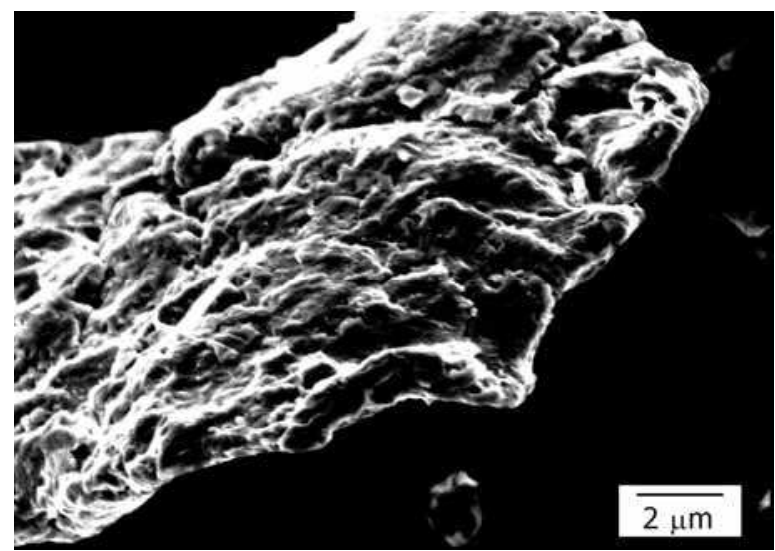

Fig. 7. SEM micrograph of composite powder containing 2 wt. $\%$ of $\mathrm{Al}_{2} \mathrm{O}_{3}$

From these Figures it is obvious that with increased $\mathrm{Al}_{2} \mathrm{O}_{3}$ content increases particle size. Average particle size of composite powders containing $1 \% \mathrm{Al}_{2} \mathrm{O}_{3}$ was $6 \mu \mathrm{m}, 1.5 \% 8 \mu \mathrm{m}$ and with $2 \% \mathrm{Al}_{2} \mathrm{O}_{3}$ around $12 \mu \mathrm{m}$. Also, these Figures show that throughout the process of mechanical alloying starting copper particles got reduced in size. Deformation strengthening induced by consecutive plastic deformations by milling media, makes previously ductile particles brittle, further leading to their breakage due to fatigue.

X-ray diffraction patterns (Figure 8.) of powders containing 1, 1.5 and $2 \mathrm{wt}$. $\% \mathrm{Al}_{2} \mathrm{O}_{3}$ show only peaks corresponding to copper, due to the small amount of $\mathrm{Al}_{2} \mathrm{O}_{3}$ in system.

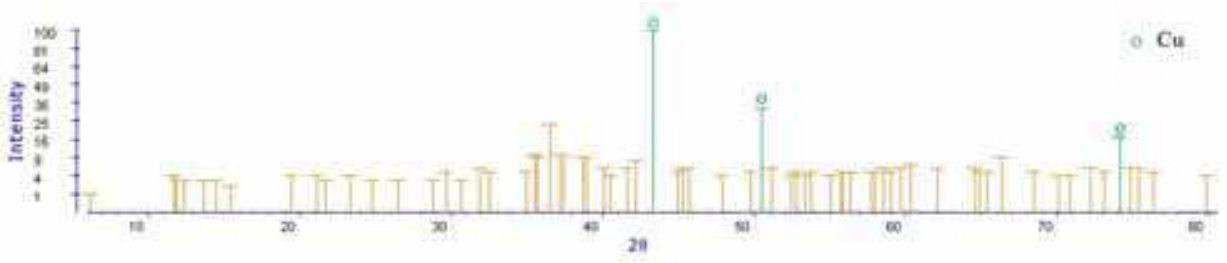

Fig. 8. XRD pattern of $\mathrm{Cu}-2 \mathrm{Al}_{2} \mathrm{O}_{3}$

\subsection{Compacts characterization}

SEM analysis of compacted powders after mechanical alloying containing 1, 1.5 and $2 \%$ of $\mathrm{Al}_{2} \mathrm{O}_{3}$ sintered at $875^{\circ} \mathrm{C}$ for $1 \mathrm{~h}$ is presented in Figures 9-11.

From the presented SEM analysis it is confirmed that with increase of alumina content grain size increases from $1 \mu \mathrm{m}$ for $\mathrm{Cu}-1 \mathrm{Al}_{2} \mathrm{O}_{3}$ up to $15-20 \mu \mathrm{m}$ for $\mathrm{Cu}-2 \mathrm{Al}_{2} \mathrm{O}_{3}$. Also, sintered compacts exhibit annealing twins and sub-grain boundaries for all three compositions. Twinning might have occurred during the high temperature sintering stage.

Conditions for twins formation are achieved when large number of obstacles is formed in crystal, blocking dislocation movement. Dislocations are accumulated on obstacles causing increase of internal strain in local areas, which together with external strain induce twins formation. Presence of twins indicated lower mobility of dislocations, in other words stabilization of dislocation structure, which is primary condition for improvement of mechanical properties of dispersion strengthened materials. 


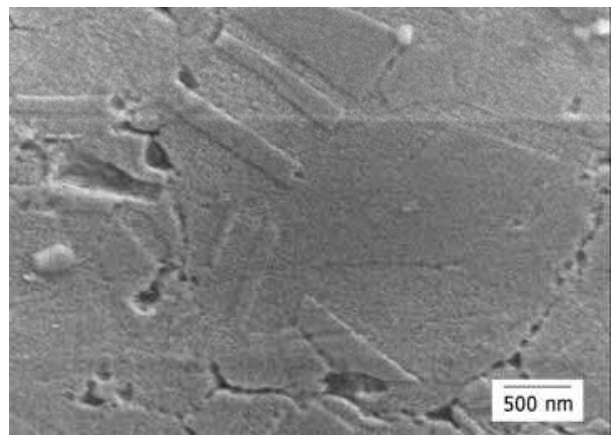

Fig. 9. SEM micrograph of $\mathrm{Cu}-1 \mathrm{Al}_{2} \mathrm{O}_{3}$

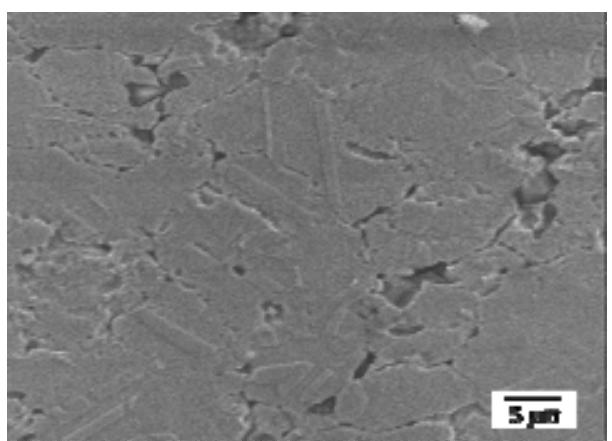

Fig. 10. SEM micrograph of $\mathrm{Cu}-1 \cdot 5 \mathrm{Al}_{2} \mathrm{O}_{3}$

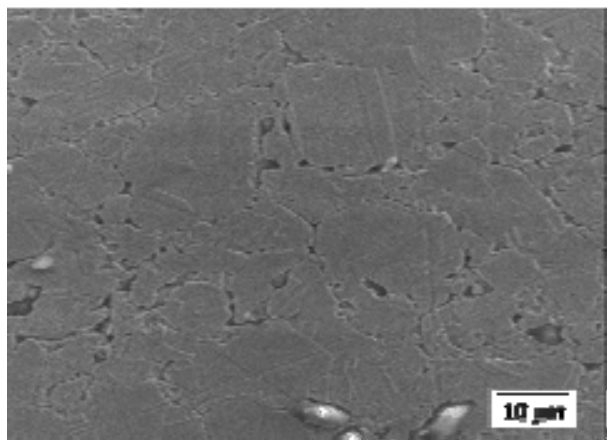

Fig. 11. SEM micrograph of $\mathrm{Cu}-2 \mathrm{Al}_{2} \mathrm{O}_{3}$

Size of sub-grains similar to ones presented in Figures 9-11 are expected to be preserved under the influence of temperature as a result of dispersed $\mathrm{Al}_{2} \mathrm{O}_{3}$ particles blocking subgrain boundaries and increasing recrystallization temperature, rendering these materials suitable for exploitation at elevated temperatures.

Also, during the period of sintering, formation of a third phase is expected (Lianga et al., $2004)$, due to the thermodynamically possible eutectic reaction of $\left(\mathrm{Cu}+\mathrm{Cu}_{2} \mathrm{O}\right)$ with $\mathrm{Al}_{2} \mathrm{O}_{3}$ at the contact surface. Through this reaction eutectic tends to expand and reacts with $\mathrm{Al}_{2} \mathrm{O}_{3}$ 
forming $\mathrm{Cu}_{\mathrm{x}} \mathrm{Al}_{\mathrm{y}} \mathrm{O}_{\mathrm{z}}$ phase, compatible with both phases at the interface (Yoshino \& Shibata, 1992; Jena et al., 2001). The formed third phase influences the dislocation structure resulting in improvement of mechanical properties, whereas good electrical conductivity is retained. According to literature (Yi et al., 1999) chemical formula of this compound might be derived as $\mathrm{CuAlO}_{2}$ or $\mathrm{CuAlO}_{4}$.

Presence of this phase in the structure and especially at the interface could impede crack propagation and result in higher interface fracture energy (Reimanis et al., 1997).

Figure 12 presents EDS analysis of produced composites with 1, 1.5 and $2 \mathrm{wt}$. $\% \mathrm{Al}_{2} \mathrm{O}_{3}$.
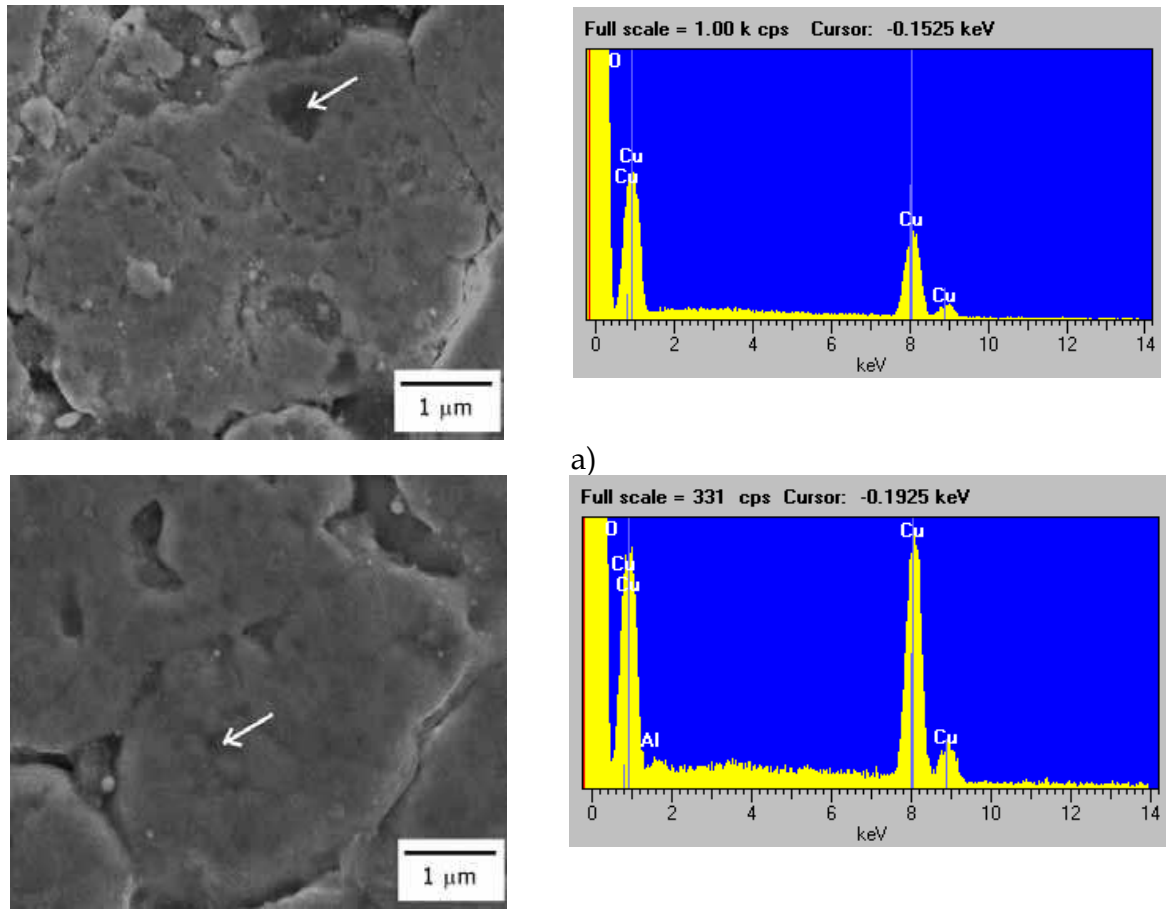

a)

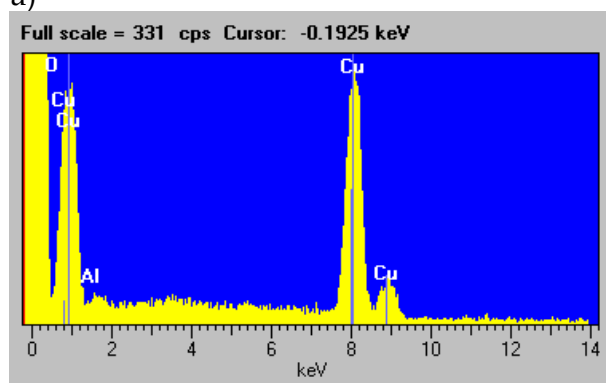

b)
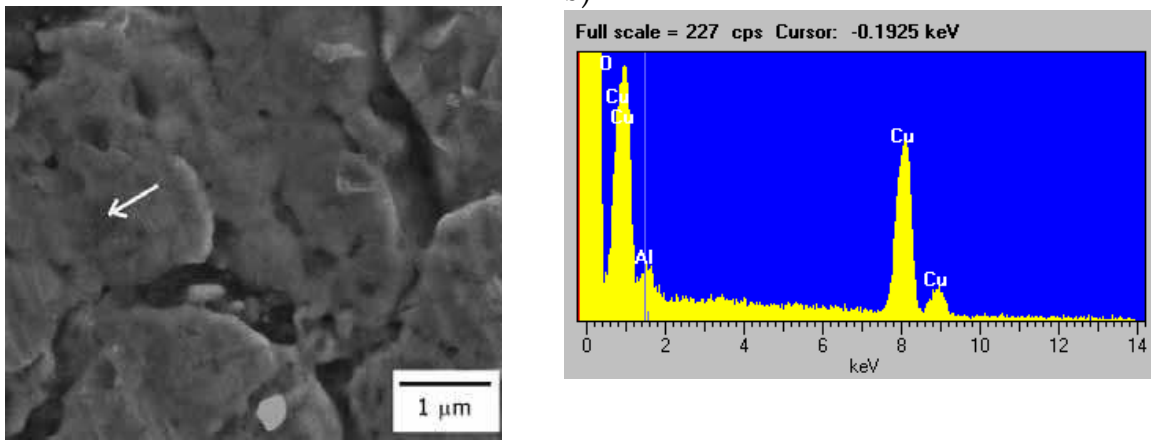

c)

Fig. 12. EDS analysis of marked spots in $\mathrm{SEM}$ micrographs of $\mathrm{Cu}-\mathrm{Al}_{2} \mathrm{O}_{3}$ composite with a) 1 ; b) 1.5 and c) 2 wt. $\% \mathrm{Al}_{2} \mathrm{O}_{3}$ 
Presented EDS results show that in the composites with $\mathrm{Cu}-1 \mathrm{Al}_{2} \mathrm{O}_{3}$ aluminum was not detected in the structure, indicating that the whole quantity of $\mathrm{Al}_{2} \mathrm{O}_{3}$ is incorporated in the copper matrix. With increase of $\mathrm{Al}_{2} \mathrm{O}_{3}$ content, aluminum is detected which suggests occurrence of segregations in the structure and formation of aluminum-rich regions. These results suggest that the new synthesis method is more suitable for composite materials containing maximum $1 \mathrm{wt}$. $\% \mathrm{Al}_{2} \mathrm{O}_{3}$. This amount could be fully incorporated in the base-metal matrix playing a role as an obstacle to dislocations, grain and sub-grain boundaries movement. However, this role is diminished with increase of $\mathrm{Al}_{2} \mathrm{O}_{3}$ content by formation of aluminumrich regions. Furthermore, Figure 12 shows better compaction for sintered compacts with lower $\mathrm{Al}_{2} \mathrm{O}_{3}$ content, which is supported by porosity measurements presented in Table 1.

\begin{tabular}{|l|l|l|l|l|l|l|}
\hline Sample & Min, $\mu m$ & Max, $\mu m$ & Mean, $\mu m$ & Std Error & StdDev. & Vv, \% \\
\hline $\mathrm{Cu}-1 \mathrm{Al}_{2} \mathrm{O}_{3}$ & 0,23 & 2,41 & 1,21 & 0,06 & 0,43 & 7,638 \\
\hline $\mathrm{Cu}-1.5 \mathrm{Al}_{2} \mathrm{O}_{3}$ & 0,18 & 4,46 & 1,34 & 0,10 & 0,72 & 7,835 \\
\hline $\mathrm{Cu}-2 \mathrm{Al}_{2} \mathrm{O}_{3}$ & 0,45 & 4,32 & 1,41 & 0,11 & 0,70 & 8,561 \\
\hline
\end{tabular}

Table 1. Statistical data for the porosity measurements for the samples with different $\mathrm{Al}_{2} \mathrm{O}_{3}$ content sintered at $875^{\circ} \mathrm{C} / 1 \mathrm{~h}$

These results are also confirmed by measurements of hardness and electrical conductivity as presented in following tables and figures.

Results of HRF hardness measurements are presented in Table 2.

\begin{tabular}{|c|c|c|c|c|c|}
\hline$t, \min$ & 725 & 775 & 825 & 875 & 925 \\
\hline \multicolumn{6}{|c|}{$\mathrm{Cu}-1 \mathrm{Al}_{2} \mathrm{O}_{3}$} \\
\hline 15 & 52 & 49 & 50 & 52 & 42 \\
\hline 30 & 52 & 54 & 50 & 50 & 52 \\
\hline 60 & 53 & 46 & 48 & 50 & 46 \\
\hline 90 & 48 & 52 & 44 & 45 & 40 \\
\hline 120 & 47 & 46 & 46 & 52 & 44 \\
\hline \multicolumn{6}{|c|}{$\mathrm{Cu}-1.5 \mathrm{Al}_{2} \mathrm{O}_{3}$} \\
\hline 15 & 42 & 42 & 40 & 42 & 40 \\
\hline 30 & 48 & 44 & 40 & 46 & 38 \\
\hline 60 & 44 & 44 & 42 & 40 & 42 \\
\hline 90 & 42 & 43 & 39 & 42 & 38 \\
\hline 120 & 44 & 39 & 40 & 39 & 43 \\
\hline \multicolumn{6}{|c|}{$\mathrm{Cu}-2 \mathrm{Al}_{2} \mathrm{O}_{3}$} \\
\hline 15 & 42 & 29 & 22 & 26 & 19 \\
\hline 30 & 26 & 27 & 12 & 20 & 19 \\
\hline 60 & 30 & 24 & 22 & 26 & 20 \\
\hline 90 & 24 & 26 & 15 & 20 & 16 \\
\hline 120 & 30 & 26 & 13 & 23 & 22 \\
\hline
\end{tabular}

Table 2. HRF hardness of sintered $\mathrm{Cu}-\mathrm{Al}_{2} \mathrm{O}_{3}$ composites

Results show that with increase of temperature and time of sintering, HRF values slightly and unevenly decrease. Increase of $\mathrm{Al}_{2} \mathrm{O}_{3}$ content has significant effect on hardness. It was expected that increase of $\mathrm{Al}_{2} \mathrm{O}_{3}$ content in structure would result with an increase of 
hardness, but the results show an opposite trend. With increase of $\mathrm{Al}_{2} \mathrm{O}_{3}$ from 1 to $1.5 \mathrm{wt}$ \% there is a slight decrease in HRF values, while increase up to $2 \mathrm{wt} . \% \mathrm{Al}_{2} \mathrm{O}_{3}$ provokes a rather significant decrease in HRF. Possible reasons for this behavior is ascribed to a positive effect on dispersion strengthening of the copper matrix which occurred when amount of $\mathrm{Al}_{2} \mathrm{O}_{3}$ dispersoide is up to $1 \mathrm{wt}$ \%, whereas further increase of $\mathrm{Al}_{2} \mathrm{O}_{3}$ content has a negative effect on hardness as previously postulated by EDS analysis (Fig. 12). This problem supposedly may be solved using hot extrusion process.

Electrical conductivity measurements of composites with different $\mathrm{Al}_{2} \mathrm{O}_{3}$ content at various sintering conditions are presented in Table 3.

\begin{tabular}{|c|c|c|c|c|c|}
\hline${ }_{t, \min } \mathrm{T},{ }^{\circ} \mathrm{C}$ & 725 & 775 & 825 & 875 & 925 \\
\hline \multicolumn{6}{|c|}{$\mathrm{Cu}-1 \mathrm{Al}_{2} \mathrm{O}_{3}$} \\
\hline 15 & 54,88 & 59,90 & 56,83 & 55,05 & 55,19 \\
\hline 30 & 53,94 & 55,39 & 56,48 & 57,16 & 56,06 \\
\hline 60 & 55,44 & 54,61 & 56,28 & 56,69 & 55,51 \\
\hline 90 & 58,00 & 55,13 & 54,54 & 55,25 & 54,81 \\
\hline 120 & 56,37 & 54,24 & 55,15 & 56,43 & 55,87 \\
\hline \multicolumn{6}{|c|}{$\mathrm{Cu}-1.5 \mathrm{Al}_{2} \mathrm{O}_{3}$} \\
\hline 15 & 42,76 & 42,49 & 43,51 & 43,86 & 43,81 \\
\hline 30 & 45,07 & 42,52 & 42,51 & 44,02 & 47,81 \\
\hline 60 & 40,94 & 43,27 & 45,48 & 49,59 & 49,88 \\
\hline 90 & 39,86 & 41,87 & 42,63 & 46,72 & 48,08 \\
\hline 120 & 43,19 & 39,11 & 42,76 & 45,80 & 48,80 \\
\hline \multicolumn{6}{|c|}{$\mathrm{Cu}-2 \mathrm{Al}_{2} \mathrm{O}_{3}$} \\
\hline 15 & 32,66 & 32,54 & 30,71 & 30,35 & 31,25 \\
\hline 30 & 29,25 & 31,27 & 29,92 & 31,13 & 40,70 \\
\hline 60 & 31,93 & 30,89 & 31,72 & 36,94 & 39,99 \\
\hline 90 & 31,35 & 31,72 & 31,76 & 37,61 & 39,35 \\
\hline 120 & 30,53 & 31,66 & 31,66 & 33,43 & 41,21 \\
\hline
\end{tabular}

Table 3. Electrical conductivity of sintered $\mathrm{Cu}-\mathrm{Al}_{2} \mathrm{O}_{3}$ composites, \%IACS

With increase of $\mathrm{Al}_{2} \mathrm{O}_{3}$ content in composite materials values of electrical conductivity decreases.

Values of electrical conductivity are over 55\% IACS for compacts with $1 \mathrm{wt} \% \mathrm{Al}_{2} \mathrm{O}_{3}$, which correspond to a dispersion strengthened copper alloys intended for application at elevated temperatures. The limitation value for application is 50\% IACS (Grant et al., 1984).

Measured values of harness, as well as electrical conductivity are highly dependant on $\mathrm{Al}_{2} \mathrm{O}_{3}$ content and not so much on sintering conditions.

\subsection{Characterization of samples after thermo-mechanical treatment}

After consolidation of the obtained powders, the compacted samples were uniaxially compressed by cold rolling, reduction degree up to $30 \%$. In order to determine the stability at higher temperatures, the rolled samples were annealed at temperature of $800^{\circ} \mathrm{C}$ in one hour in the hydrogen atmosphere.

Cold rolling of samples was performed in two steps: first $15 \%$ of size reduction and second of $30 \%$. During cold rolling samples with 1.5 and $2 \%$ of $\mathrm{Al}_{2} \mathrm{O}_{3}$ were degraded, due to inhomogeneous structure and distribution of $\mathrm{Al}_{2} \mathrm{O}_{3}$, as presented in Figure 12 and increased 
porosity with increase of $\mathrm{Al}_{2} \mathrm{O}_{3}$ (Table 1). Insufficient packing caused formation of cracks in the middle of the sample and disabled sample structure to endure forces of cold plastic deformation.

Considering the presented research results, shown also in (Korać et al., 2010), which suggest that the best combination of mechanical and electrical properties was achieved in the systems with 1 wt. $\% \mathrm{Al}_{2} \mathrm{O}_{3}$ sintered at $875^{\circ} \mathrm{C} / 1 \mathrm{~h}$, so further experimental results will be related to these compacts only.

SEM analysis of samples after two stages of size reduction and after heat treatment $(\mathrm{HT})$ is presented in Figure 13.

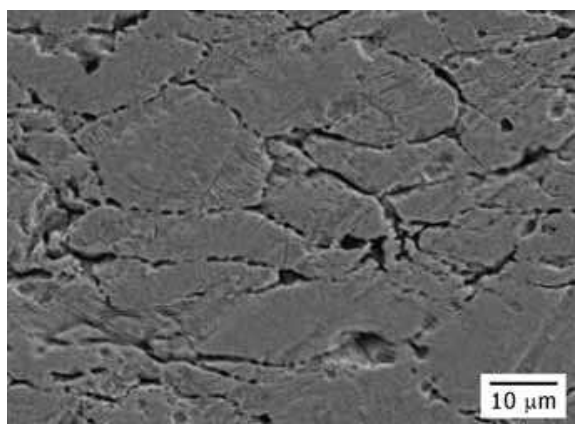

a)

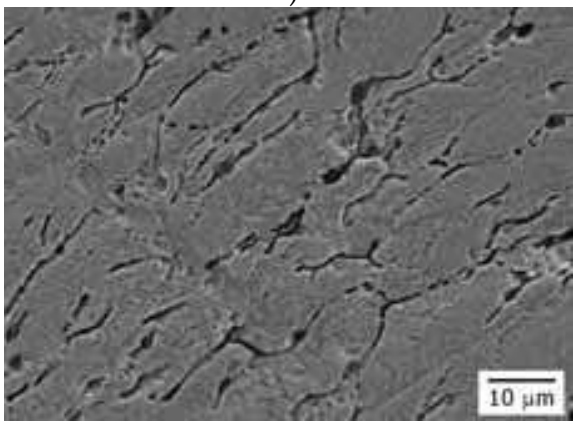

b)

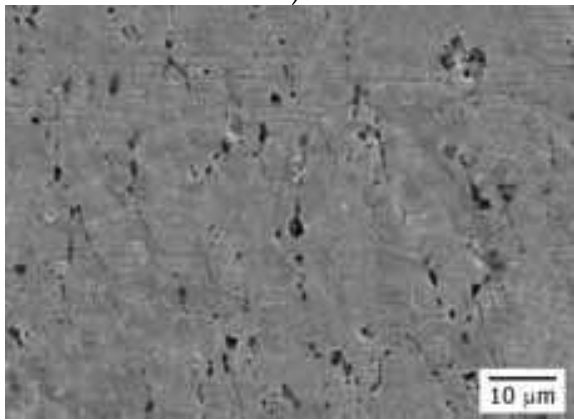

c)

Fig. 13. SEM micrographs of compacts after cold rolling and heat treatment a) size reduction $15 \%, b$ ) size reduction $30 \%$ and c) heat treated 
Statistical data on porosity of samples after cold rolling and heat treatment are presented in Table 4. Data for sintered samples is also incorporated in this Table for comparison.

\begin{tabular}{|l|l|l|l|l|l|l|}
\hline Sample & Min, $\mu \mathrm{m}$ & Max, $\mu \mathrm{m}$ & Mean, $\mu \mathrm{m}$ & StdError & StdDev. & Vv, \% \\
\hline sintered & 0,23 & 2,41 & 1,21 & 0,06 & 0,43 & 7,638 \\
\hline $15 \%$ & 0,36 & 2,84 & 0,91 & 0,07 & 0,490 & 7,01 \\
\hline $30 \%$ & 0,29 & 2,14 & 0,69 & 0,04 & 0,337 & 5,52 \\
\hline HT & 0,16 & 1,56 & 0,55 & 0,03 & 0,29 & 4,507 \\
\hline
\end{tabular}

Table 4. Statistical data for the porosity measurements for the samples with different $\mathrm{Al}_{2} \mathrm{O}_{3}$ content sintered at $875^{\circ} \mathrm{C} / 1 \mathrm{~h}$ after cold rolling and heat treatment

In the structure of the samples subjected to cold plastic deformation performed by rolling, porosity is also relatively evenly distributed, with a clearly visible porosity of the directed orientation.

The comparative analysis of the porosity testing results of the samples subjected to cold plastic deformation by rolling and the sintered samples indicates the significant porosity in the sintered samples both from the aspect of the pore size, and also from the aspect of their volume share. In the cold deformed samples by rolling, it is clearly noticeable the accumulation of the pores at grain boundaries, which indicates that the pores in the moment of contact with the grain edge during its movement have been too large to be absorbed by the grain edge and disappeared in it, which has resulted in stopping the grain edge to move and its growth.

Rolling can change the distribution and the size of secondary phase, as well as to reduce the number of pores. After rolling, the particles of $\mathrm{Al}_{2} \mathrm{O}_{3}$ become more dispersive, while the relative density increases (Korać et al., 2008).

The porosity in the structure of the samples subjected to heat treatment after cold plastic deformation is relatively evenly distributed. The pores are arbitrarily oriented, and the shape of the pores is irregular. Based on relative distribution of porosity and statistical data, the size of pores is in the range from $160 \mathrm{~nm}$ to $1.56 \mu \mathrm{m}$ with medium diameter of $550 \mathrm{~nm}$. The volume share of porosity is $4.5 \%$.

The comparative analysis of the results of the porosity tests on the sintered samples, the samples subjected to cold plastic deformation by rolling and the HT samples points to significant porosity of the sintered samples and the samples subjected to cold plastic deformation by rolling in relation to the annealed samples as from the aspect of the pore size, so from the aspect of their volume share.

Results of hardness measurements in function size reduction and heat treatment for selected sintering temperature of $875^{\circ} \mathrm{C}$ are presented in Fig. 14. and for electrical conductivity in Fig.15.

From Fig.14 it could be noticed that with increase of size reduction hardness values are increasing up to the level of $90 \mathrm{HRF}$ indicating stabilization of dislocation structure. Also, curves of dependence HRF-time are stabilizing. Stabilization of curve could be the result of structure compaction and reduction of pore volume fraction in structure. After heat treatment harness values decrease up to the value of $55 \mathrm{HRF}$. Change of curve slope could be detected for sintering time of $60 \mathrm{~min}$. After $30 \%$ reduction at $60 \mathrm{~min}$ slope is changing into plateau. Heat treated samples exhibit slight decrease of hardness values after $60 \mathrm{~min}$. 


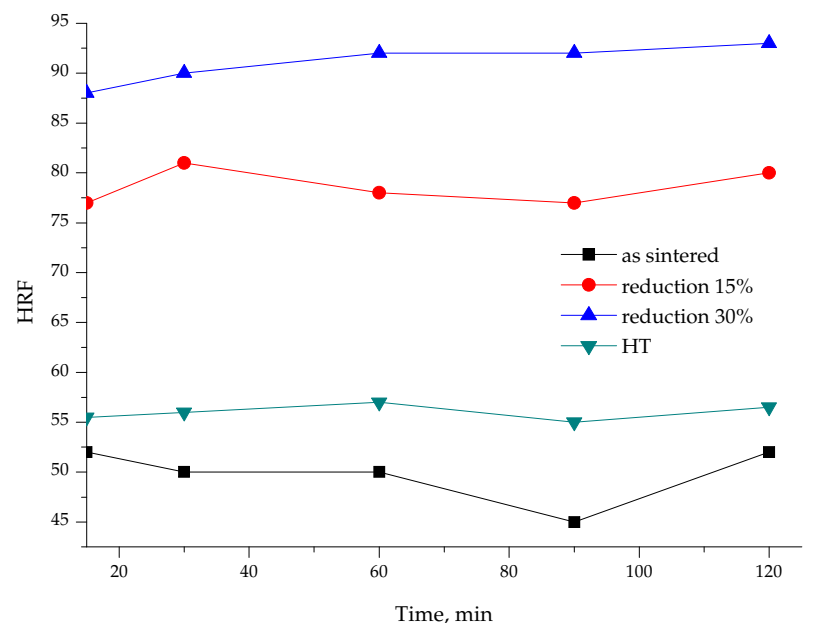

Fig. 14. Dependence of HRF hardness from size reduction and heat treatment for selected sintering temperature of $875^{\circ} \mathrm{C}$

Values of electrical conductivity for as sintered samples are over 55\% IACS, which correspond to dispersion strengthened copper alloys intended for application at elevated temperatures. With increase of size reduction electrical conductivity is increasing up to the $59.5 \%$ IACS. After heat treatment electrical conductivity continues to increase up to $60.75 \%$ IACS for sintering time of $60 \mathrm{~min}$, when plateau is reached. After $60 \mathrm{~min}$ of sintering hardness and electrical conductivity both reached constant values, indicating completed stabilization of structure.

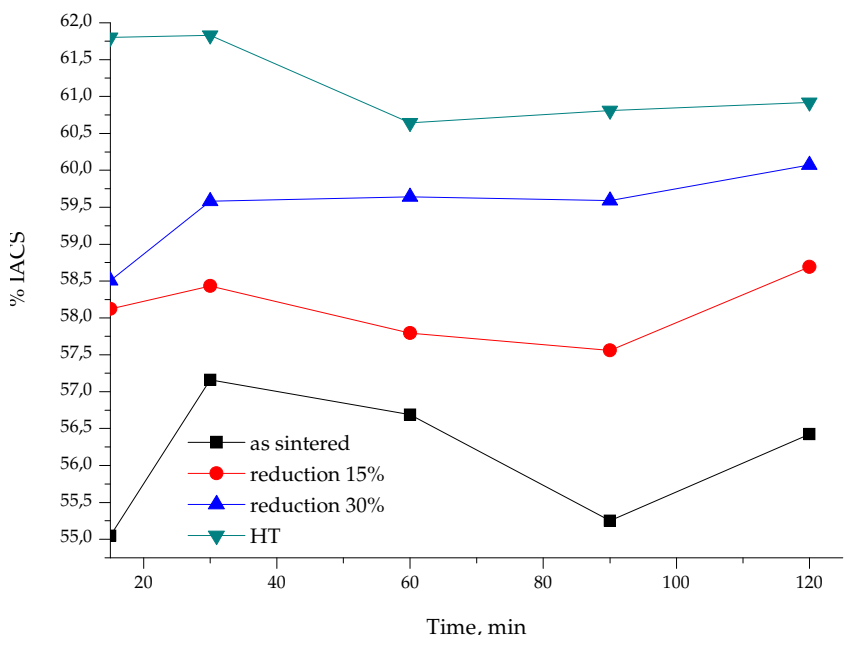

Fig. 15. Dependence of electrical conductivity from size reduction and heat treatment for selected sintering temperature of $875^{\circ} \mathrm{C}$

Aiming to evaluate the stability of structure for the sintered samples and each phase of the thermo-mechanical treatment process, the examinations on tribological properties were performed. 
It is well known that the HT metals with the surface centered cubic crystal structure have significantly higher resistance to erosive wear in comparison to metals with the spatially centered cubic crystal structure of similar hardness. Cold rolling prior to wear testing does not bring significant improvement in resistance to erosive wear. Also, reducing the speed rate of the erosive wear is achieved with an increase in the index of the deformation hardening. Increasing in the index of the deformation strengthening effects on increasing the value of critical voltage that is required to starting with localize the deformation in the process of wear (Liu et al. 2007).

Tribological tests have shown that the best resistance to wear have the samples after heat treatment (Fig. 16), which can be explained by the fact that after annealing recrystalization and characteristic growth of the grain do not occur, due to block in movement of the grain boundaries homogeneously distribution of alumina and formation of the third phase, identified in (Jena et al., 2004; Jena et al., 2001; Lee \& Kim, 2004, Anđić, 2007, Korać, 2009). This is confirmed by the microstructural examinations of the analyzed samples.

Based on the results of quantitative analysis and tribological examinations, it can be concluded that the effect of porosity has a significant influence on the tribological properties, that is, as the volume share of porosity reduces as tribological properties improve.

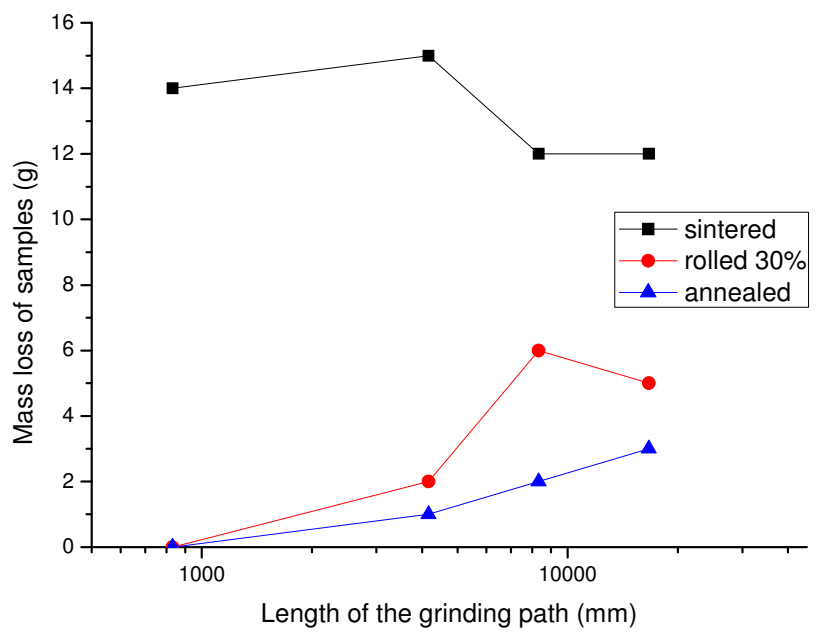

Fig. 16. Wear resistance of the sintered $\left(875^{\circ} \mathrm{C} / 60 \mathrm{~min}\right)$, rolled and annealed sample

The significant influence on the tribological properties has multiple strengthening mechanisms of the analyzed systems schematically presented in Figure 17.

In the observed system, strengthening the base of copper is achieved by dispersion strengthening, due to the dispersion of fine particles of $\mathrm{Al}_{2} \mathrm{O}_{3}$ in the base, strengthening by grain boundaries, because of the third phase appearance, as well as the deformation strengthening and strengthening by annealing. During mechanical alloying the coating copper particle with the particles of the composite $50 \% \mathrm{Al}_{2} \mathrm{O}_{3}$ occurs, which is built into its surface. Along with the process of sintering occurs the formation of the compact structure and formation of the third phase on the grain boundary, which causes strengthening on the grain boundaries. Due to the plastic deformation occurs the deformation strengthening, and after heat treatment occurs the strengthening by annealing, which is confirmed by the results of the tribological examinations. 


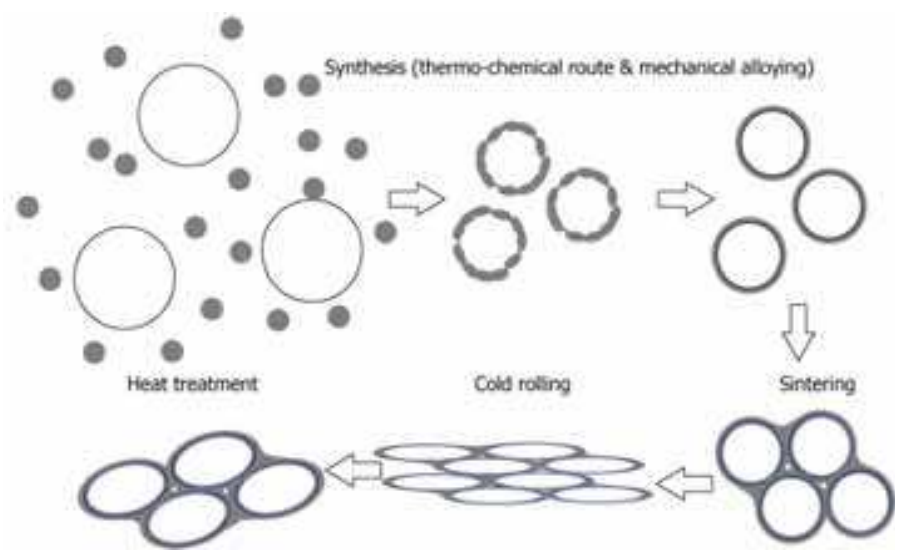

Fig. 17. Proposed multiple strengthening mechanisms

\section{Conclusion}

Synthesis of nanocomposite $\mathrm{Cu}-\mathrm{Al}_{2} \mathrm{O}_{3}$ powder suitable for obtaining multiple strengthened systems could be successfully performed by combination of the thermo-chemical procedure and the mechanical alloying. To optimize the whole scope of properties that are expected from these materials, the combination of thermo-chemical procedures and the procedure of mechanical alloying is a completely new approach to the synthesis of powders. Thus obtained powders allow obtaining the final product with the excellent effects of strengthening.

Presented results show possibility of usage composite powders based on copper and alumina synthesized by novel method for production of compacts with suitable properties for exploitation at elevated temperatures, i.e. increased hardness with electrical conductivity appropriate for oxide dispersion strengthened copper alloys intended for application at elevated temperatures. Achieved values after thermo-mechanical treatment for hardness are $57 \mathrm{HRF}$ and for electrical conductivity $61 \% \mathrm{IACS}$.

Limitation for dispersoide content is $1 \mathrm{wt}$. \%, due to the decomposition of compacts with higher $\mathrm{Al}_{2} \mathrm{O}_{3}$ content during mechanical processing. Increased $\mathrm{Al}_{2} \mathrm{O}_{3}$ content could be achieved by using hot extrusion process.

\section{Acknowledgment}

Presented research is part of projects TR19032 and TR34033 financially supported by Ministry of Science and Technological Development, Republic of Serbia.

\section{References}

Afshar A. \& Simchi A. (2008), Abnormal grain growth in alumina dispersion-strengthened copper produced by an internal oxidation process, Scripta Materialia, 58 (11), pp. 966-969

Ahn J-H., Song I-H. \& Hahn Y-D. (1996), Cu-Based Cermets Prepared By Mechanical Alloying, Materials Transactions JIM, 37 (4), pp. 733-737

Anđić Z. (2007), Ph. D. Thesis, Faculty of Technology and Metallurgy, University of Belgrade (in Serbian) 
Anđić Z., Korać M., Kamberović Ž., Vujović A. \& Tasić M. (2007), Analysis of the Properties of a $\mathrm{Cu}-\mathrm{Al}_{2} \mathrm{O}_{3}$ Sintered System based on Ultra Fine and Nanocomposite Powders, Science of Sintering, 39(2), pp. 145-152

Anđić Z., Korać M., Tasić M., Raić K. \& Kamberović Ž. (2006), The synthesis of ultra fine and nanocomposite powders based on copper, silver and alumina, Kovove materialy, 44(3), pp. $145-150$

ASTM standard (2007), MNL 56 - Guide to friction, wear and erosion testing

Brocchi E.A., Motta M.S., Solorzano I.G., Jena P.K. \& Moura F.J. (2004), Alternative chemicalbased synthesis routes and characterization of nano-scale particles, Materials Science and Engineering B, 112 (2-3), pp. 200-205

Byrappaa K. \& Adschirib T. (2007), Hydrothermal technology for nanotechnology, Progress in Crystal Growth and Characterization of Materials, 53 (2), pp. 117-166

Grant J.N., Lee A. \& Lou M. (1984), in: Proceedings:"High Conductivity Copper and Aluminium Alloys", Eds. E. Ling and P.W. Taubenblat, The Metallurgical Society of AIME, California, pp. 103-111.

Iskandar F., Gradon L. \& Okuyama K. (2003), Control of the morphology of nanostructured particles prepared by the spray drying of a nanoparticle sol, Journal of Colloid and Interface Science 265 (2), pp. 296-303

Jena P. K., Brocchi E. A. \& Motta M. S. (2001), Characterization of $\mathrm{Cu}-\mathrm{Al}_{2} \mathrm{O}_{3}$ nano-scale composites synthesized by in situ reduction, Materials Science and Engineering $\mathrm{C}$, 15 (1-2), pp. 175-177

Jena P. K., Brocchi E. A. \& Motta M. S. (2001), In-situ formation of Cu- $\mathrm{Al}_{2} \mathrm{O}_{3}$ nano-scale composites by chemical routes and studies on their microstructures, Materials Science and Engineering A, 313 (1-2), pp. 180-186

Jena P. K., Brocchi E. A., Solórzano I. G. \& Motta M. S. (2004), Identification of a third phase in $\mathrm{Cu}-\mathrm{Al}_{2} \mathrm{O}_{3}$ nanocomposites prepared by chemical routes, Materials Science and Engineering A, 371 (1-2), pp. $72-78$

Karwan-Baczewska J., Gotman I., Gutmanas E.Y. \& Shapiro M. (2005), Small particles with better contacts make nanocomposites kings of conductivity, Metal Powder Report 60 (6), pp. 28-34

Koch C., Bulk Behavior of Nanostructured Materials (1999), Chapter 6, Nanostructure Science and Technology A Worldwide Study, National Science and Technology Council (NSTC), USA, pp. 93-112

Korać M. (2005), Master Thesis, Faculty of Technology and Metallurgy, University of Belgrade (in Serbian)

Korać M. (2009), Ph. D. Thesis, Faculty of Technology and Metallurgy, University of Belgrade (in Serbian)

Korać M., Kamberović Ž. \& Filipović M. (2008), Determination of $\mathrm{Al}_{2} \mathrm{O}_{3}$ particle size in $\mathrm{Cu}-$ $\mathrm{Al}_{2} \mathrm{O}_{3}$ nanocomposite materials using UV spectrophotometry, Metalurgija, 14 (4), pp. 279-284 (in Serbian)

Korać M., Kamberović Ž., Anđić Z. \& Filipović M. (2010), Sintered materials based copper and alumina powders synthesised by novel method, Science of Sintering, 42(1), pp. 81-90

Korać M., Kamberović Ž., Tasić M. and Gavrilovski M., Nanocomposite powders for new contact materials based on copper and alumina Chemical Industry \& Chemical Engineering Quarterly 14(4) (2008), 215-218

Lee D. W. \& Kim B. K. (2004), Nanostructured $\mathrm{Cu}-\mathrm{Al}_{2} \mathrm{O}_{3}$ composite produced by thermochemical process for electrode application, Materials Letters, 58 (3-4), pp. 378-383 
Lee D. W., Ha G. H.\& Kim B. K. (2001), Synthesis of $\mathrm{Cu}-\mathrm{Al}_{2} \mathrm{O}_{3}$ nano composite powder, Scripta Materialia 44 (8-9), pp. 2137-2140

Liang S., Fan Z., Xua L. \& Fang L. (2004), Kinetic analysis on $\mathrm{Al}_{2} \mathrm{O}_{3} / \mathrm{Cu}$ composite prepared by mechanical activation and internal oxidation, Composites Part A: Applied Science and Manufacturing, 35 (12), pp. 1441-1446

Liu X-B., Jia C-C., Chen X-H. \& Gai G-S. (2007), Microstructures and properties of $1.0 \% \mathrm{Al}_{2} \mathrm{O}_{3} / \mathrm{Cu}$ composite treated by rolling, The Transactions of Nonferrous Metals Society of China 17, Special issuse International Conference of Nonferrous Materials (ICNFM) Part IIB, pp. 626-629

McCandlish L. E., Kear B. H. \& Bhatia S. J. (1994), Spray conversion process for the production of nanophase composite powders, United States Patent, 5.352.269

Moriarty P. (2001), Nanostructured materials, Reports on Progress in Physics, 64 (3), pp. 297-381

Motta M.S., Brocchi E.A., Solórzano I.G. \& Jena P.K. (2004), Multidisciplinary Microscopy Research and Education, FORMATEX, pp. 215-223.

Naser J., Ferkel H. \& Riehemann W. (1997), Grain stabilization of copper with nanoscaled Al2O3-powder, Material Science and Engineering A, 234-236, pp. 470-473

Okuyama K. \& Lenggoro I. W. (2003), Preparation of nanoparticles via spray route, Chemical Engineering Science, 58 (3-6), pp. 537-547

Plascencia G. \& Utigard T.A. (2005), High temperature oxidation mechanism of dilute copper aluminium alloys, Corrosion Science 47 (5), pp. 1149-1163

Reimanis I., Trumble K., Rogers K. \& Dalglrish B. (1997), Influence of $\mathrm{Cu}_{2} \mathrm{O}$ and $\mathrm{CuAlO}_{2}$ Interphases on Crack Propagation at $\mathrm{Cu} /-\mathrm{A} 12 \mathrm{O} 3$ Interfaces, Journal of the American Ceramic Society, 80 (2), pp. 424-432

Ristić M., Fundamental Problems of the Science of Materials, TF Čačak and Serbian Academy of Science and Arts, Čačak, 2003, p. 98

Ristić M.M. \& Milošević S.Đ. (2006), Frenkel's Theory of Sintering, Science of Sintering, 38 (1), pp. 7-11

Ruys A.J. \& Mai Y-W. (1999), The nanoparticle-coating process: a potential sol-gel route to homogeneous nanocomposites, Materials Science and Engineering: A, 265 (1-2), pp. 202-207

Tian B., Liua P., Songa K., Lia Y., Liua Y., Rena F. \& Sua J. (2006), Microstructure and properties at elevated temperature of a nano- $\mathrm{Al}_{2} \mathrm{O}_{3}$ particles dispersionstrengthened copper base composite, Materials Science and Engineering: A, 435436, pp. $705-710$

Trojanová Z., Ferkel H., Luká P., Naser J. \& Riehemann W. (1999), Thermal stability of copper reinforced by nanoscaled and microscaled alumina particles investigated by internal friction, Scripta Materialia, 40 (9), pp. 1063-1069

Wu Y., Zhang Y., Huang X. \& Guo J. (2001), Preparation of platelike nano alpha alumina particles, Ceramic International, 27 (3), pp. 265-268

Yi S., Trumble K.P. \& Gaskell D.R. (1999), Thermodynamic analysis of aluminate stability in the eutectic bonding of copper with alumina, Acta Materialia 47 (11), pp. 3221-3226

Yoshino Y. \& Shibata T. (1992), Structure and Bond Strength of a Copper-Alumina Interface, Journal of the American Ceramic Society 75 (10), pp. 2756-2760

Yuana G-Q., Jiang H-F., Lina C. \& Liaoa S-J. (2007), Shape- and size-controlled electrochemical synthesis of cupric oxide nanocrystals, Journal of Crystal Growth, 303 (2), pp. 400-406 


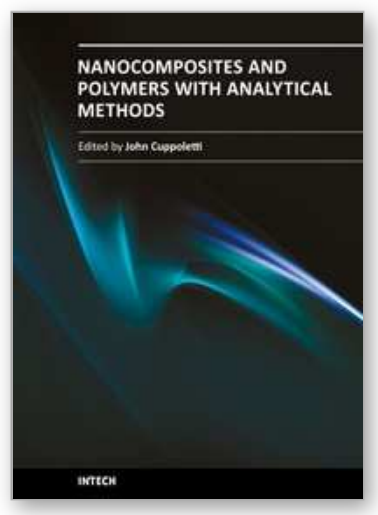

\author{
Nanocomposites and Polymers with Analytical Methods \\ Edited by Dr. John Cuppoletti
}

ISBN 978-953-307-352-1

Hard cover, 404 pages

Publisher InTech

Published online 09, August, 2011

Published in print edition August, 2011

This book contains 16 chapters. In the first part, there are 8 chapters describing new materials and analytic methods. These materials include chapters on gold nanoparticles and Sol-Gel metal oxides, nanocomposites with carbon nanotubes, methods of evaluation by depth sensing, and other methods. The second part contains 3 chapters featuring new materials with unique properties including optical non-linearities, new materials based on pulp fibers, and the properties of nano-filled polymers. The last part contains 5 chapters with applications of new materials for medical devices, anodes for lithium batteries, electroceramics, phase change materials and matrix active nanoparticles.

\title{
How to reference
}

In order to correctly reference this scholarly work, feel free to copy and paste the following:

Marija Korać, Żeljko Kamberović, Zoran Anđić and Mirjana Filipovic (2011). Sintered Materials Based on Copper and Alumina Powders Synthesized by a Novel Method, Nanocomposites and Polymers with Analytical Methods, Dr. John Cuppoletti (Ed.), ISBN: 978-953-307-352-1, InTech, Available from:

http://www.intechopen.com/books/nanocomposites-and-polymers-with-analytical-methods/sintered-materialsbased-on-copper-and-alumina-powders-synthesized-by-a-novel-method

\section{INTECH}

open science | open minds

\section{InTech Europe}

University Campus STeP Ri

Slavka Krautzeka 83/A

51000 Rijeka, Croatia

Phone: +385 (51) 770447

Fax: +385 (51) 686166

www.intechopen.com

\section{InTech China}

Unit 405, Office Block, Hotel Equatorial Shanghai

No.65, Yan An Road (West), Shanghai, 200040, China

中国上海市延安西路65号上海国际贵都大饭店办公楼405单元

Phone: +86-21-62489820

Fax: +86-21-62489821 
(C) 2011 The Author(s). Licensee IntechOpen. This chapter is distributed under the terms of the Creative Commons Attribution-NonCommercialShareAlike-3.0 License, which permits use, distribution and reproduction for non-commercial purposes, provided the original is properly cited and derivative works building on this content are distributed under the same license. 